\title{
Phylogenetic analysis of flatfish (Order Pleuronectiformes) based on mitochondrial 16 rDNA sequences*
}

\author{
BELÉN G. PARDO ${ }^{1}$, ANNIE MACHORDOM ${ }^{2}$, FAUSTO FORESTI ${ }^{3}$, \\ FÁBIO PORTO-FORESTI ${ }^{3}$, MARISA F. C. AZEVEDO ${ }^{3}$, RAFAEL BAÑÓN ${ }^{4}$, \\ LAURA SÁNCHEZ ${ }^{1}$ and PAULINO MARTÍNEZ ${ }^{1}$
}

\begin{abstract}
${ }^{1}$ Departamento de Genética, Universidad de Santiago de Compostela, 27002 Lugo, Spain. E-mail: paumarpo@lugo.usc.es ${ }^{2}$ Museo Nacional de Ciencias Naturales (CSIC), José Gutiérrez Abascal, 2, 28006, Madrid, Spain. ${ }^{3}$ Departamento de Morfología, Instituto de Biociencias, Universidad Estadual Paulista, 510, 18.618-000, Botucatu, Brazil. ${ }^{4}$ Unidade Técnica de Pesca de Baixura (UTPB), Dirección Xeral de Recursos Mariños-Consellería de Pesca e Asuntos Marítimos, Rúa do Valiño 63-65, 15703, Santiago de Compostela, Spain.
\end{abstract}

SUMMARY: The phylogenetic relationships of the order Pleuronectiformes are controversial and at some crucial points remain unresolved. To date most phylogenetic studies on this order have been based on morpho-anatomical criteria, whereas only a few sequence comparisons based studies have been reported. In the present study, the phylogenetic relationships of 30 flatfish species pertaining to seven different families were examined by sequence analysis of the first half of the $16 \mathrm{~S}$ mitochondrial DNA gene. The results obtained did not support percoids as the sister group of pleuronectiforms. The monophyletic origin of most families analyzed, Soleidae, Scophthalmidae, Achiridae, Pleuronectidae and Bothidae, was strongly supported, except for Paralichthyidae which was clearly subdivided into two groups, one of them associated with high confidence to Pleuronectidae. The analysis of the 16S rRNA gene also suggested the monophyly of Pleuronectiforms as the most probable hypothesis and consistently supported some major interfamily groupings.

Keywords: Pleuronectiformes, 16S mtDNA, phylogenetic analysis.

RESUMEN: ANÁLISIS FILOGENÉTICO EN PECES PLANOS (ORDEN PLEURONECTIFORMES) MEDIANTE SECUENCIAS DEL ADNr 16S MITOCONDRIAL. - Las relaciones filogenéticas del orden Pleuronectiformes son controvertidas, permaneciendo aún algunos puntos esenciales en discusión. La mayoría de los estudios filogenéticos realizados hasta la actualidad en este Orden han estado basados en criterios morfo-anatómicos y sólo unos pocos en la comparación de secuencias. En el presente estudio fueron examinadas las relaciones filogenéticas de 30 especies de peces planos pertenecientes a 7 familias distintas mediante la secuenciación de la primera mitad del gen $16 \mathrm{~S}$ del ADN mitocondrial. Los resultados obtenidos no apoyaron a los Perciformes como grupo hermano de los Pleuronectiformes. El origen monofilético de la mayoría de las familias analizadas, Soleidae, Scophthalmidae, Achiridae, Pleuronectidae y Bothidae, resultó consistente, salvo Paralichthydae que apareció claramente subdividida en 2 grupos, uno de ellos asociado con un alto nivel de confianza con Pleuronectidae. El análisis del gen ARNr 16S también reveló como hipótesis más probable la monofilia del orden Pleuronectiformes y permitió detectar consistentemente relaciones interfamiliares constituyendo grupos mayores en la filogenia del orden.

Palabras clave: Pleuronectiformes, 16S mtDNA, analisis filogenético.

\section{INTRODUCTION}

Pleuronectiformes represent a very specialized assemblage within fish. Their age is not well estab-

*Received February 17, 2004. Accepted March 14, 2005. lished but they probably date back to the Eocene (Lauder and Liem, 1983; Vernau et al., 1994). This order comprises approximately 115 genera and around 600 species (Norman, 1934; Hubbs, 1945; Amaoka, 1969; Nelson, 1994), three-quarters of them show a tropical distribution and about one- 
quarter are northerly and southerly distributed in temperate waters. Remarkably, most species analyzed pertain to the last group because of their economic interest both for fisheries and farming, some of which are successfully cultured in farms. The position of Pleuronectiformes in relation to other major fish groups and the phylogenetic relationships within the order are still problematic. Most studies have been carried out based on morpho-anatomical characters (Hubbs, 1945; Lauder and Liem, 1983; Ahlstrom et al., 1984; Hensley and Ahlstrom, 1984; Chapleau, 1993), and only a few molecular phylogenetic analyses have been performed to date on this order (Vernau et al., 1994; Tinti et al., 1999; Berendzen and Dimmick, 2002).

One of the major questions concerning flatfish phylogeny is the presumptive monophyly of the order. This hypothesis is the most widely accepted, based on morphological data (Regan, 1910; Norman, 1934; Hubbs, 1945; Lauder and Liem, 1983; Hensley and Ahlstrom, 1984; Chapleau, 1993). It is supported by the putative existence of three synapomorphic characters (Chapleau, 1993): i) ontogeny characterized by migration of one eye, ii) anterior position of the origin of the dorsal fin, and iii) the presence of a recessus orbitalis (accessory organ associated with eyes), and also by molecular data in the recent study by Berendzen and Dimmick (2002). However, Kyle (1921), Chabanaud (1949), and Amaoka (1969), have claimed a polyphyletic origin, suggesting a multiple origin from different groups of symmetrical fishes.

Perciforms have long been suggested to be the sister group of Pleuronectiformes. Regan (1910), Norman (1934), Hubbs (1945) and Amaoka (1969), have emphasized the relationship between Psettodes, the ancient representative of the order, and Perciformes. However, the anatomical evidence used to support this relationship is a combination of generalized percoid characters and the wide Percoidei group is most probably polyphyletic (Chapleau, 1993; Johnson and Patterson, 1993; Nelson, 1994; Hensley, 1997).

The systematic of flatfish is poorly known and classification has been mainly performed using morpho-anatomic characters. The exhaustive revision by Chapleau (1993), with morphological characters pointed out that previous classifications might be intuitive, simplistic and phylogenetically misleading. According to this author, the three suborders introduced by Hensley and Ahlstrom (1984), and Ahlstrom et al. (1984), should be reclustered into only two: Psettodoidei and Pleuronectoidei. In addition, this author proposed the existence of twelve families, suggesting that the subfamilies Achirinae Pleuronectinae, Poecilopsettinae, Rhombosoleidae and Samarinae should be elevated to the rank of family. More recently, Cooper and Chapleau (1998), also included the family Paralichthodidae which comprises Paralichthodes algoensis, a problematic species previously classified within Samarinae. However, the relationships among the families of the order would not change, being essentially those proposed by Lauder and Liem (1983), including the poor resolution in the suborder Pleuronectoidei due to the large number of polytomies. On the other hand, phylogeny of Pleuronectiformes using molecular data has been limited to a small number of species and/or families. In the work by Vernau et al. (1994), based on protein electrophoresis and DNA/DNA hybridization, the family Soleidae appeared, in accordance with Hubbs (1945), as the most primitive within the Pleuronectiformes, while others point to this family together with Cynoglossidae as the most specialized families of the group (Chapleau, 1993). More recent sequence analyses (Tinti et al., 1999; Exadactylos and Thorpe, 2001), were limited both in the number of species and families, and mainly devoted to solve intrafamily relationships. The recent report by Berendzen and Dimmick (2002), represents the most complete study on flatfish phylogeny to date based on mtDNA sequences, and although most families of the order were included in their work, the number and origin of species within families were not always representative. Taking into account the consensus that Psettodidae is the most ancient family of the group, the relationships between most families are very controversial.

In order to gain a better understanding of the evolutionary relationships of Pleuronectiformes, we have analyzed the first half of the mitochondrial (mt) 16S rDNA gene to generate a molecular phylogeny with 30 species belonging to seven out of thirteen families described in this order (Chapleau, 1993; Nelson, 1994). We have also taken data from the GenBank, both to obtain a better representation of some families as well as to get some insight into genetic differentiation between putative assemblages within some species of the group. For this analysis we have chosen the mtDNA 16S rRNA gene due to its effectiveness in previous studies for establishing the evolutionary relationships of lineages of similar divergence in fish (Alves-Gómes et al., 
TABLE 1. - Species analyzed in this study both from natural sampling and GenBank data following the classification by Chapleau (1993), and Cooper and Chapleau (1998).

\begin{tabular}{|c|c|c|c|}
\hline Family & Species & Source & GenBank accession $n_{0}$. \\
\hline \multirow[t]{4}{*}{ Scophthalmidae } & Scophthalmus maximus & NE Atlantic & AY359664 \\
\hline & S. rhombus & NE Atlantic & AY359665 \\
\hline & Lepidorhombus boscii & NE Atlantic & AY359666 \\
\hline & L. whiffiagonis & NE Atlantic & AY359667 \\
\hline \multirow[t]{2}{*}{ Pleuronectidae } & Platichthys flesus & NE Atlantic & AY359670 \\
\hline & Pleuronectes platessa & NE Atlantic & AY359673 \\
\hline \multirow[t]{6}{*}{ Paralichthyidae } & Paralichthys olivaceus & GenBank & AB028664 \\
\hline & $P$. patagonicus & SW Atlantic & AY359657 \\
\hline & Citharichthys macrops & SW Atlantic & AY359656 \\
\hline & Etropus crossotus & SW Atlantic & AY359654 \\
\hline & Syacium papillosum & SW Atlantic & AY359655 \\
\hline & Pseudorhombus arsius & Indian Ocean & AY359658 \\
\hline \multirow[t]{2}{*}{ Cynoglossidae } & Cynoglossus cynoglossus & Indian Ocean & AY359669 \\
\hline & Symphurus tessellatus & SW Atlantic & AY359668 \\
\hline \multirow{14}{*}{ Soleidae } & Solea solea & GenBank & AF112845 \\
\hline & Solea senegalensis & NE Atlantic & AY359661 \\
\hline & S. senegalensis & GenBank & AF148802 \\
\hline & S. lascaris & NE Atlantic & AY359662 \\
\hline & S. lascaris & GenBank & AF112849 \\
\hline & S. kleini & GenBank & AF112847 \\
\hline & S. impar & GenBank & AF112848 \\
\hline & Microchirus variegatus & GenBank & AF112851 \\
\hline & M. ocellatus & GenBank & AF112850 \\
\hline & Monochirus hispidus & GenBank & AF112852 \\
\hline & Buglossidium luteum & NE Atlantic & AY359663 \\
\hline & Buglossidium luteum & GenBank & AF112853 \\
\hline & Bathysolea profundicula & NE Atlantic & AY359659 \\
\hline & Dicologoglossa cuneata & NE Atlantic & AY359660 \\
\hline \multirow[t]{3}{*}{ Bothidae } & Bothus ocellatus & SW Atlantic & AY359652 \\
\hline & Arnoglossus laterna & NE Atlantic & AY359653 \\
\hline & A. imperialis & NE Atlantic & AY359651 \\
\hline \multirow[t]{2}{*}{ Achiridae } & Achirus lineatus & SW Atlantic & AY359671 \\
\hline & Trinectes paulistanus & SW Atlantic & AY359672 \\
\hline
\end{tabular}

1995; Farias et al., 1999; Tinti et al., 1999; Tringali et al., 1999; Hanel and Sturmbauer, 2000), and also because it is technically easy to obtain sequence information by selective gene amplification with universal primers (Brown, 1985).

\section{MATERIALS AND METHODS}

\section{Source of species analyzed}

A total of 33 sequences from 30 species pertaining to seven of the thirteen families defined morphologically in this order (Chapleau, 1993; Cooper and Chapleau, 1998), were analyzed (Table 1). Most species were sampled in the Atlantic Ocean on the Galician (NW Spain) and Brazilian coasts, the rest of the samples were collected in the Cantabric Sea and Indian Ocean. Ten of the sequences were taken from the GenBank reported by Saitoh et al. (1995), Tinti and Piccinetti (2000) and Tinti et al. (2000). Three species (Solea senegalensis, S. lascaris, Buglossidium luteum) were analyzed from samples collected in both Atlantic and Mediterranean areas
(Adriatic, Ionian and Mediterranean Sea; GenBank) to check for the existence of major genetic assemblages within these species.

\section{Molecular analysis}

Genomic DNA samples were obtained from fresh, frozen or ethanol-preserved muscle or liver tissues, homogenized in SSTNE extraction buffer (Blanquer, 1990) plus SDS (0.1\%). Proteinase K (90 $\mathrm{mg} / \mathrm{mL}$ ) was added and samples incubated overnight at $56^{\circ} \mathrm{C}$. After $1 \mathrm{~h}$ at $37^{\circ} \mathrm{C}$ with $0.2 \%$ RNAse $(10 \mathrm{mg} / \mathrm{mL})$, the total DNA was purified by standard phenol:chloroform extraction (Sambrook et al., 1989) and ethanol precipitation.

A section of mtDNA genome from the $16 \mathrm{~S}$ rRNA gene (about $644 \mathrm{bp}$ ) was amplified with standard PCR techniques using the primers $16 \mathrm{SH}$ 5' CGCCTGTTTATCAAAAACAT 3' and 16SR 5' CCGGTCTGAACTCAGATCACGT 3' (Palumbi et al., 1991). Around $150 \mathrm{ng}$ of DNA template were amplified in a $50 \mu \mathrm{L}$ reaction mixture containing 1 $\mathrm{mM}$ of each primer, $200 \mathrm{mM}$ of each dNTP, 2.5 $\mathrm{mM} \mathrm{MgCl}_{2}, 2.5 \mathrm{U} \mathrm{Taq}$ polymerase (Amersham 
Pharmacia Biotech), and the corresponding buffer plus ddH2O. The thermal cycling conditions were: $94^{\circ} \mathrm{C}(5 \mathrm{~min}), 33$ cycles at $93^{\circ} \mathrm{C}(1 \mathrm{~min}), 55^{\circ} \mathrm{C}(1$ $\mathrm{min}), 72^{\circ} \mathrm{C}(3 \mathrm{~min})$, and a final extension step at $72^{\circ} \mathrm{C}(10 \mathrm{~min})$. PCR products were visualized in $0.8 \%$ agarose gels stained with ethidium bromide and purified using the ConcertTM Rapid PCR Purification System (Gibco BRL).

Both strands were sequenced for accuracy in each individual. Double-stranded DNA sequencing reactions were prepared using the Thermo Sequenase fluorescent labelled primer cycle sequencing kit with 7-deaza-dGTP (Amersham Pharmacia Biotech) for an ALF Express II sequencer. Sequences from the 30 species analyzed were initially aligned using the sequence alignment program of the ALFwinTM Sequence Analyser 2.00 (Amersham Pharmacia Biotech) and then using the alignment program CLUSTAL W (Thompson et al., 1994). A final hand correction was applied before the phylogenetic analysis to examine the alignment generated and adjust it to make sure the final alignment made biological sense.

The correspondence between the alignment obtained and the proposed secondary structure of 16S rDNA of fish (Alves-Gómes et al., 1995) was evaluated to identify the segments corresponding to the loops and stems of our sequence. This allowed us to test the weight given to each subregion according to its presumptive evolutionary rate. An increasingly progressive weight from 0.5 to 1 was given to loops with regard to stems, according to the higher evolutionary rates of the former. The number of transitions and transversions was estimated using a maximum likelihood approach for all pairs of taxa, as well as the number of indels. Indels were included in the analysis as a fifth character state.

\section{Phylogenetic analysis}

When constructing phylogenies from molecular data both the composition of the ingroup and the choice of the outgroup can strongly affect whether the correct topology is attained. The uneven rates of molecular evolution can strongly affect the ability of tree-building algorithms to find the correct tree. Outgroup taxa can be assigned, either to a single sister clade (preferably the closest one), or through the addition of single taxa from different clades (Smith, 1994). We checked the two possibilities outlined above by testing all the species of Perciformes available in the GenBank (22 species). Alternatively,

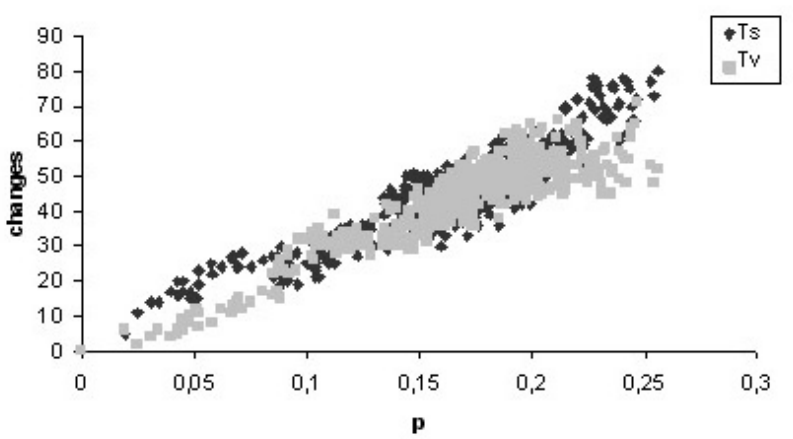

FIG. 1. - Relationship between uncorrected mean divergence (p) for all pairwise comparisons and the number of transitional (Ts) and transversional $(\mathrm{Tv})$ changes.

some species members of more distantly related clades, such as Salmo salar (Salmoniformes, Protacanthopterygii), Aulopus purpurissatus and Chlorophthalmus sp (Aulopiformes, Cyclosquamata), and Hyporhamphus regularis (Atheriniformes, Atherinomorpha), were tested as outgroups to determine their effect on the overall tree topology.

Most parts of the analyses were executed using the PAUP v4.0b3 package (Swofford, 2000), using different algorithms for phylogenetic reconstruction: neighbour joining (NJ), maximum parsimony (MP), and maximum likelihood (ML). By plotting the absolute number of changes against uncorrected divergence values we analyzed the saturation for transition and transversion changes in the sequence analyzed (Fig. 1). The best model of evolution that fitted to our data was obtained using the Modeltest v3.0 program (Posada and Crandall, 1998). Thus, the GTR $+\mathrm{I}+\mathrm{G}$ (General Time Reversible, Lavane et al., 1984; Rodríguez et al., 1990), model was used both for ML and distance-based methods to obtain phylogenetic trees. Parsimony analysis was performed following a heuristic search with tree bisection reconnection (TBR) branch swapping, with 10 replicates of random stepwise addition. Maximum likelihood analysis was performed according to a Quartet Puzzling search (1000 replications). Confidence of phylogenetic hypotheses was estimated by bootstrapping (1000 replications; Felsenstein, 1985) (Fig. 3).

To estimate the posterior probability of the phylogenetic trees, Bayesian analyses were also performed (Fig. 5). The MrBayes program (Huelsenbeck and Ronquist, 2001), was run with 6 substitution types (nst=6) that a GTR $+\mathrm{I}+\mathrm{G}$ model performs. The MCMCMC (Metropolis-coupled Markov chain Monte Carlo) algorithm was used with four Markov chains, for 1000,000 to 2000,000 generations, sample frequency every 100 genera- 
tions and eliminating the $10 \%$ of the first trees obtained that represents those that did not reach the stationarity of the likelihood values.

\section{RESULTS}

One preliminary task was to choose the best outgroup to perform the phylogenetic analysis. When using all species of the order Perciformes available in the GenBank, they mostly appeared as a single clearly supported clade, but as a paraphyletic group within Pleuronectiformes. Additionally, the genetic distances observed with regard to Pleuronectiformes were high, and a large number of polytomies and low consistent values appeared in the trees obtained. These results suggested that it was necessary to look for other alternative species to polarize the trees.

In the other strategy, we added taxa that were presumably more distantly related. The best results

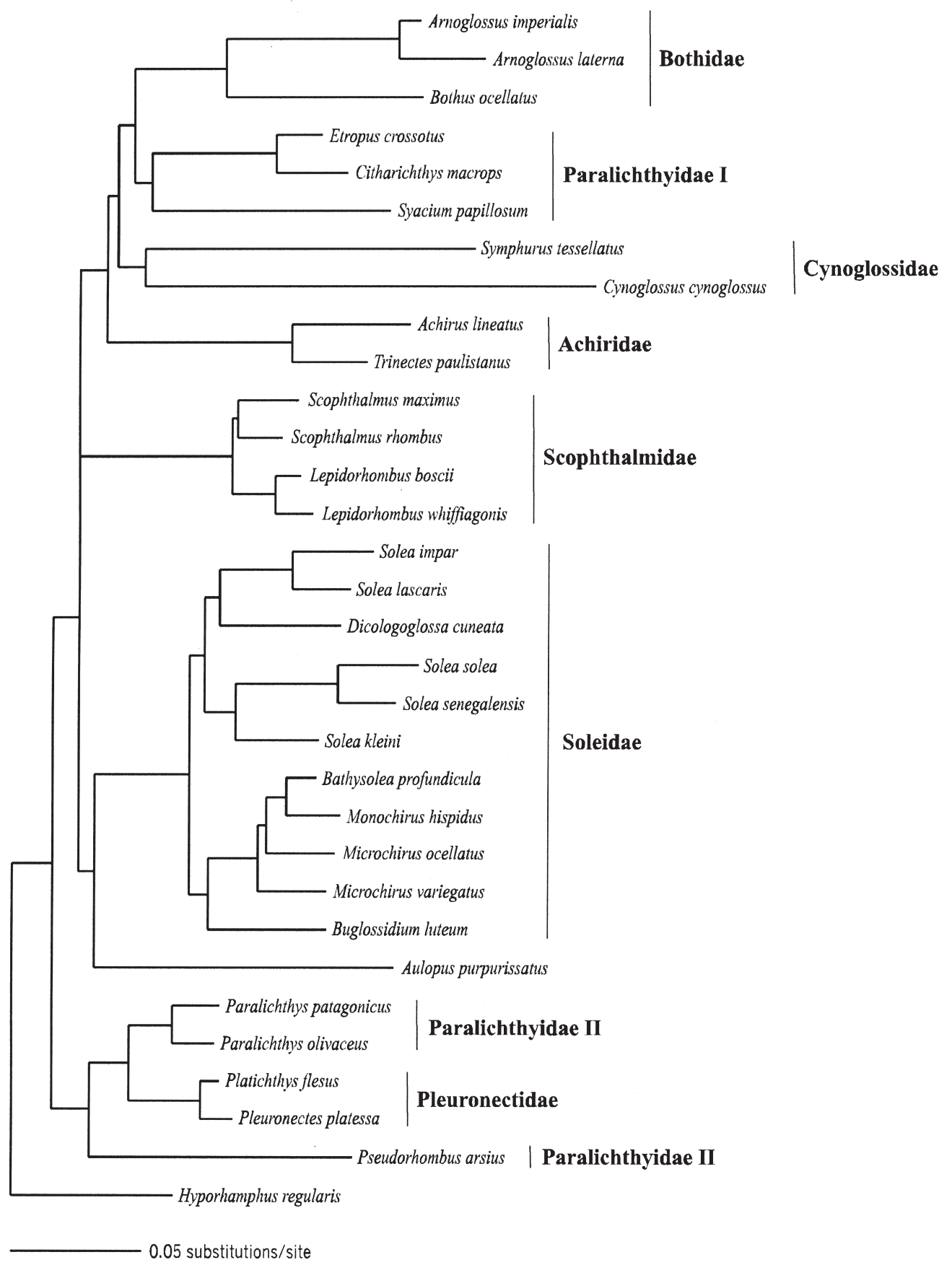

FIG. 2.- Neighbour-joining tree of the 30 species of Pleuronectiformes analyzed. 
were obtained with Aulopus purpurissatus and Hyporhamphus regularis. The number of polytomies within Pleuronectiformes decreased and the consistency values increased considerably when using these species as outgroups. Additionally, these species showed genetic distances within the range observed in the ingroup. In view of these results, we finally decided to include these last two species to polarize our analyses.

Thirty-five sequences, 33 pertaining to flatfish and 2 to the outgroups, Aulopus purpurissatus and Hyporhamphus regularis, were analyzed. The genetic subdivision analysis within three species of the order, Solea senegalensis, S. lascaris and Buglossidium luteum (Mediterranean area sequences obtained from the GenBank) are presented below. Therefore, we initially consider only the sequences of these three species collected in our sampling from the Atlantic area.

The aligned sequences from the 30 flatfish species and the outgroups of the first half of the $16 \mathrm{~S}$ mt rDNA comprised $644 \mathrm{bp}$, exhibiting 326 constant sites and 239 phylogenetically informative for parsimony analysis. The average percentages of nucleotides for all taxa were: A, 29.07\%; C, 25.83\%; G, $22.36 \%$; T, 22.74\%. This content was essentially the same in all the taxa analyzed $(\mathrm{P}=1.00)$.

The transition $(\mathrm{Ts}) /$ transversion $(\mathrm{Tv})$ ratio was 1.25. Taking into consideration that choosing putatively divergent outgroups could increase the proportion of homoplasies, we checked the saturation of Ts and Tv changes by plotting the absolute number of changes against uncorrected percentage divergence values (Fig. 1). The graphic evidenced that Ts and $\mathrm{Tv}$ increased linearly with $\mathrm{p}$ distances, indicating that substitutions were not saturated in the ingroup or between the ingroup and the outgroups. Therefore, all the information was retained for further analyses.

The percentage of divergence between the 32 species, including the outgroups, ranged from 0 for the two sequences of Solea senegalensis from the Mediterranean and Atlantic area, to 0.256 between Lepidorhombus whiffiagonis and Cynoglossus cynoglossus. This last species together with the other species from the Cynoglossidae family, Symphurus tessellatus, presented the highest distances from all other taxa. The two outgroups showed distances within the range observed in the ingroup. Another remarkable feature was the genetic distances obtained between the two species of the family Pleuronectidae, Platichthys flesus and
Pleuronectes platessa, and the two species of Paralichthys analyzed. These distances ranged from 0.062 to 0.071 , and were of the same order of closely related genera, in spite of belonging to different families according to morphological characters.

As indicated above, the species of the family Cynoglossidae evidenced high genetic distances with long branches in the tree obtained (Fig. 2). As these fast-evolving species distorted the topology of the tree (low confidence values) probably due to the increment of homoplasies ("long branch attraction"; Le et al., 1993), we decided to exclude them initially from the phylogenetic analysis.

The four analyses carried out, Bayesian, maximum parsimony (MP), maximum likelihood (ML) and Neighbour-Joining (NJ), which took into account the parameters estimated, yielded similar trees (Fig. 3). However, the best levels of resolution were obtaining with the Bayesian, NJ and MP methods, especially at the internal nodes. The Bayesian, MP and NJ methods presented 16 out of 19,14 out of 19 and 13 out of 20 resolved nodes respectively, with bootstrap values above $90 \%$, while ML resolved consistently only 4 out of 19 nodes. The more terminal nodes were in general highly supported, that is, those which clustered species of the same genera or family, while the relationships among the different families showed lower consistency, with lesser concordance across the different methods applied.

There were two main discrepancies between the four methods within the families analyzed. One affected the relationship of Dicologoglossa cuneata with the remaining species of Soleidae: ML clustered D. cuneata with the species of the genus Solea, whereas the Bayesian, NJ and MP approaches branched it at the base of the family. The second discrepancy involved the species of the family Scophthalmidae (genus Scophthalmus and Lepidorhombus), where only the Bayesian and MP methods showed two branches, clustering each species within its genus as suggested by morphological data. As outlined, most families analyzed showed sound confidence values across the four methods performed, suggesting their monophyletic origin. All families, excluding Paralichthyidae, evidenced bootstrap values above $90 \%$. However, the family Paralichthyidae appeared split into two consistent subgroups: Firstly into the Cyclopsetta group, defined morphologically by Hensley and Ahlstrom (1984), and represented in this study by three of the four genera that make it up, Syacium, 


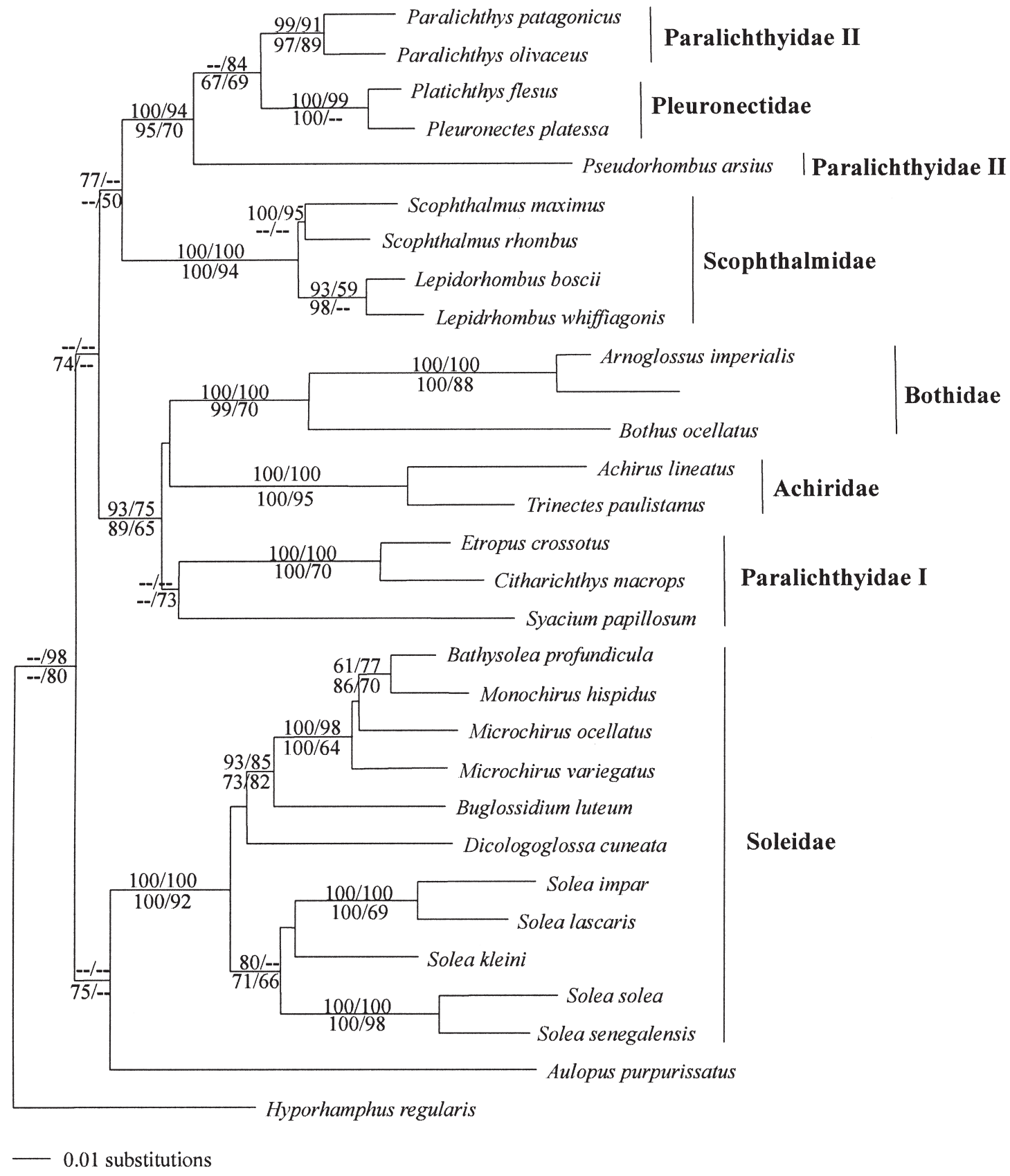

FIG. 3. - Phylogenetic relationships between the taxa of Pleuronectiformes analyzed. Numbers above branches represent the posterior probability (in percentage) or bootstrap values obtained for Bayesian inference and maximum-parsimony, and below for neighbour-joining and maximum-likelihood. When a particular branch was not recovered by a specific method or the posterior probability or bootstrap value were under 50\%, two hyphens replace the corresponding bootstrap value.

Citharichthys and Etropus, that appeared related to the families Bothidae and Achiridae with the four methods of reconstruction employed (Paralichthyidae I). The other group included the genera Pseudorhombus and Paralichthys, and was soundly clustered with the family Pleuronectidae (Paralichthyidae II).

Although some of the phylogenetic reconstruction methods showed values above $50 \%$ at the most internal nodes, concerning the monophylia of the group or the relationships among families, these results were not consistent across all methods analyzed. The best supported result was the splitting of Pleuronectiformes into two groups, one constituted by the family Soleidae, and the other by the remaining families. Within this group, one of the most striking findings was the relationship between three paralichthyids (Paralichthyidae II) and the pleuronectids, supported by a bootstrap value above 90\% in Bayesian, MP and NJ. Additionally, the rela- 


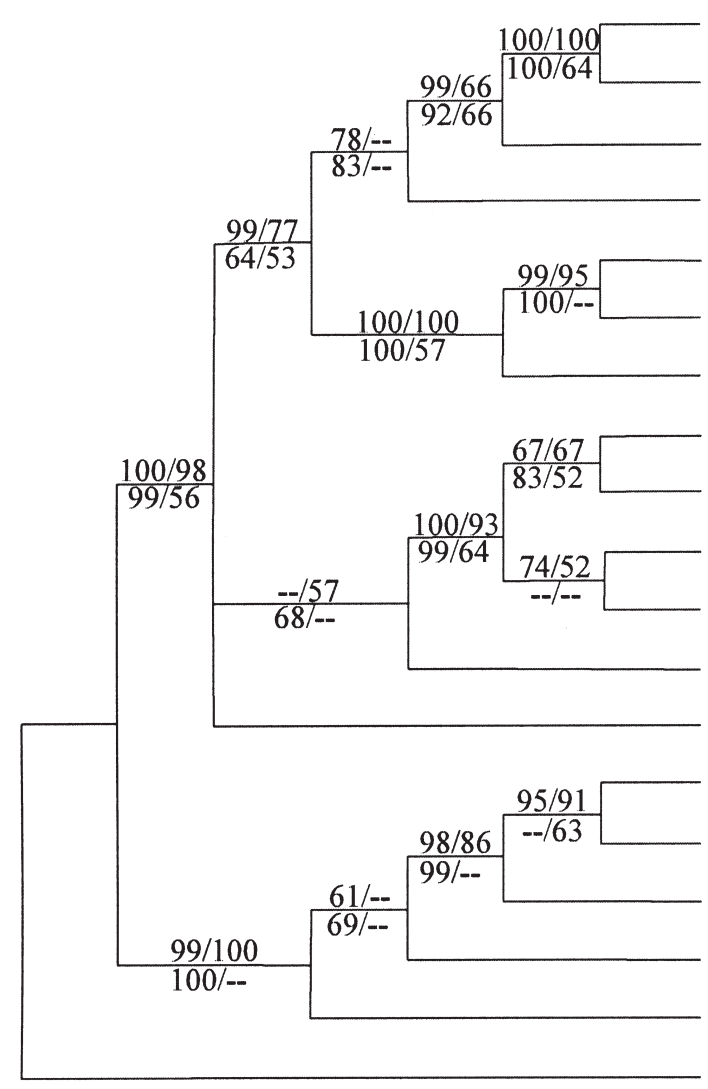

Solea senegalensis

Solea senegalensis 2

Solea solea

Solea kleini

Solea impar

Solea lascaris 2

Solea lascaris

Soleidae

Bathysolea profindicula

Monochirus hispidus

Microchirus ocellatus

Microchirus variegatus

Buglossidium luteum

Dicologoglossa cuneata

Buglossidium luteum 2

Lepidorhombus boscii

Lepidorhombus whiffiagonis

Scophthalmidae

FIG. 4. - Phylogenetic tree obtained with the 18 sequences of 15 flatfish species belonging to the families Soleidae and Scophthalmidae, plus Aulopus purpurissatus as outgroup. The tree species (Solea senegalensis, S. lascaris and Buglossidium luteum) of Mediterranean origin are indicated as "2". The order of the values on the branches is the same as in Figure 3.

tionship between Achiridae, Bothidae and the Cyclopsetta group of Paralichthydae (Paralichthyidae I) appeared supported in all cases above $65 \%$, while Scophthalmidae and Pleuronectidae + Paralichthyidae II were clustered together above $50 \%$ only with the Bayesian and ML approach.

As outlined before, three species analyzed (Solea senegalensis, S. lascaris and Buglossidium luteum) were collected both from Atlantic (present work) and Mediterranean areas (GeneBank) respectively. When these sequences were introduced into the analysis (Fig. 4), the two sequences of S. senegalensis clustered together with a null genetic distance between them. The two sequences of S. lascaris constituted a single clade together with $S$. impar, in which the sequence of $S$. lascaris of Mediterranean origin clustered with $S$. impar, while our sequence from the Atlantic appeared as the basal one of the groups. The most striking result was obtained with the two sequences of $B$. luteum. The sequence from the Mediterranean appeared clustered to the family Scophthalmidae, closely related to Lepidorhombus boscii, while the sequence analyzed from the
Atlantic area was related to the family Soleidae, as expected according to morphological data.

Finally, when the two species of Cynoglossidae omitted were introduced for the bootstrap replications (data not shown), the trees obtained showed a great number of polytomies and lower support, although the two members of this family appeared grouped together.

\section{DISCUSSION}

\section{S rDNA as a Phylogenetic Marker}

Conservation of primary and secondary structures of $16 \mathrm{~S}$ rDNA from fish to land vertebrates, including humans, appears to be well supported according to different authors (Alves-Gomés et al., 1995; Orti, 1997; Stepien et al., 1997). This suggests that functional constraints exert a strong selective pressure at the molecular level. However, the rate of nucleotide substitution in this region of the mitochondrial genome is not constant across all sites and 
there appears to be different substitution rates in loops (high) and stems (low) of its secondary structure. Our results indicate that in Pleuronectiformes, the 16S rDNA as a whole has not yet reached complete saturation. Mindell and Honeycutt (1990), have suggested that transitions in both the $12 \mathrm{~S}$ and $16 \mathrm{~S}$ rRNA genes do not saturate up to $30 \%$ nucleotide divergence in other vertebrates. In our case the maximum divergence detected was lower than $26 \%$, which supports this observation. Dixon and Hillis (1993), have suggested that stems should be weighted no less than 0.8 in relation to loops. Applying different weights in our analysis of both regions did not essentially affect the results obtained, although the best supported trees were obtained when the same weight was applied, which is in accordance with the results reported by Dixon and Hillis (1993).

The values obtained for the average percentages of nucleotides were very close to those observed in other fish species (Alves-Gómes et al., 1995; Farias et al., 1999; Tringali et al., 1999), although the GC content, $48.2 \%$, was slightly higher in our study.

\section{Phylogenetic relationships within Pleuronectiformes}

Chapleau (1993), suggested that to have any scientific value, the polyphyletic hypothesis on the origin of pleuronectiforms should be based on apomorphic characters shared by different flatfish and symmetrical fish groups, which does not appear to be the case. Likewise, the first comprehensive molecular analysis of phylogenetic relationships among flatfishes by Berendzen and Dimmick (2002), strongly supports the monophyletic origin of flatfishes. The results obtained in our work by using the 16S rDNA do not definitively support any of these hypotheses, although some of the methods performed in our analysis suggest monophyly as the most probable one.

In relation to the sister group of Pleuronectiformes, in our study, when the species of perciforms available in the GenBank (22 species) were used to polarize our trees, most species appeared clustered as a single paraphyletic group within Pleuronectiformes, but with large genetic distances compared with those of the ingroup. However, some species of Atherinomorpha and Cyclosquamata (Hyporhamphus regularis and Aulopus purpurissatus, respectively), that are presumably more divergent, showed lower genetic dis- tances, and gave more statistical support to the phylogenetic trees obtained for Pleuronectiformes. Therefore, the results obtained in the present study do not support percoids being the sister group of Pleuronectiformes.

Finally, in our work, 30 species and 7 families out of 13 of the order Pleuronectiformes were analyzed using sequencing data of the first half of the $16 \mathrm{~S}$ rDNA. In relation to previous data, our results confirmed the polyphyletic origin of Paralichthyidae in agreement with Chapleau (1993) and Berendzen and Dimmick (2002). Paralichthyidae appeared divided into two groups, one group was constituted by the genera Paralichthys and Pseudorhombus (Paralichthyidae II), which were soundly related to the members of the family Pleuronectidae which were analyzed. A relationship between species of Pleuronectidae and several paralichthyid genera had been previously suggested by Tinti et al. (1999), and Berendzen and Dimmick (2002), following the analysis of mtDNA sequences. On the other hand, the remaining genera, Citharichthys, Etropus and Syacium (Paralichthyidae I), which belong to the monophyletic group Cyclopsetta (Hensley and Ahlstrom, 1984; Chapleau, 1993), appeared related to the members of the families Bothidae and Achiridae analyzed in the present study. This relationship has also been indicated by Hensley and Ahlstrom (1984), Chapleau (1993) and Berendzen and Dimmick (2002), but only between the bothids and the Cyclopsetta group. Available chromosome data also points in the same direction. The karyotypes of the family Pleuronectidae are the closest ones to the ancestral condition proposed for Pleuronectiformes (Le Grande, 1975; Pardo et al., $2001 ; 2 n=48)$. This karyotype $(2 \mathrm{n}=48)$ is also shared by Paralichthys olivaceus (Kikuno et al., 1986), while Pseudorhombus arsius shows a diploid number of $2 n=46$ (Patro and Prasad, 1981), a karyotype also present in the Pleuronectidae and easily explained by a single centric fusion from the ancestral karyotype. However, cytogenetic data of the members of the Cyclopsetta group evidenced much more evolved karyotypes (Citharichthys spilopterus: $2 \mathrm{n}=28$, Le Grande, 1975; Etropus crossotus: 2n=38, Le Grande, 1975; Sola et al., 1981), such as those observed in the families Achiridae and Bothidae $(2 n=40$, Le Grande, 1975; 2n=38, Vitturi et al., 1993, respectively). This group together with the family Cynoglossidae constitutes the most evolved karyotypes of the order Pleuronectiformes. All these data strongly suggest including the genera 
Paralichthys and Pseudorhombus in the Pleuronectidae family, and the species of the Cyclopsetta group in the Bothidae and Achiridae families, constituting a single well supported clade.

Unlike the family Paralichthyidae, the remaining families analyzed in our study appeared highly consistent as monophyletic groups. Our results support the family range for Achiridae in agreement with Chapleau and Keast (1988), and Chapleau (1993). However, it was not possible to fully establish the relationships between all the families of flatfish analyzed, like in other studies of flatfish phylogeny (Chapleau, 1993; Berendzen and Dimmick, 2002). The most supported hypothesis splits Soleidae from the remaining families as a single monophyletic group. This is in accordance with previous data, but it does not resolve the basal family within the order. Our analyses were not consistent with data obtained by Berendzen and Dimmick (2002), which recognized a close relationship between Achiridae and Soleidae. In our study Achiridae appeared consistently related to Bothidae and the group Cyclopsetta as a single clade, while the relationship between Scophthalmidae and Pleuronectidae was weakly supported.

One possible cause for our limited success at resolving some of the internal nodes in the tree of the pleuronectiform phylogeny (monophyly, sister group, family interrelationships) may be the existence of different substitution rates along the molecule (loops and stems), which could disturb the analysis, although our data suggest that this does not appear to be a major problem. Another cause concerns the possibility of a fast evolutionary radiation within Pleuronectiformes, from which each group would have evolved independently and therefore the phylogenetic signal among families is very weak. The high degree of divergence between the different families was also suggested by Vernau et al. (1994), to explain the difficulty in establishing the links between the different families of pleuronectiforms. These authors proposed two hypotheses that could explain this magnitude of divergence: i) these families share a common ancestor that is older than that proposed until now (Eocene); and ii) the evolutionary rates of this order could be higher than other related orders. The lack of a good fossil record and the difficulty for finding diagnostic marker positions in rapid radiations at the molecular level makes it difficult to rule out these hypotheses.

Research dealing with a small number of species or with unequal representation within the order taken as generalizations for the entire order should be considered with caution (Hensley, 1997). To resolve a complex phylogeny such as that seen in Pleuronectiformes, it is essential, therefore, to conduct purposeful taxonomic sampling that increases phylogenetic accuracy (Hillis, 1998). Therefore, we have analyzed jointly the $16 \mathrm{~S}$ rDNA information of our data and that of Berendzen and Dimmick (2002), making up a total of 73 species of Pleuronectiformes. The resulting Bayesian tree is presented in Figure 5, where the main clusters previously cited are also supported. As the previous analyses showed, in the present work all the families are clustered in monophyletic groups except the family Paralichthyidae that splits into two different groups (Paralichthyidae I and II, see Figure 3) and the family Citharidae. Unfortunately, excluding the closed relationship between Pleuronectidae and Paralichthyidae II and Achiridae and Poecilopsettidae the joint analysis of data could not solve the relationships between the different families, since the relationship between Paralichthyidae I, Bothidae, Cynoglossidae, Samaridae, Citharidae and Psettodes on one side and Scophthalmidae, Achiridae and Poecilopsettidae on the other was not soundly established.

Finally, we have analyzed the possible existence of genetic assemblages within some species pertaining to Mediterranean and Atlantic areas (Solea senegalensis, S. lascaris and Buglossidium luteum), which are regions that define strong genetic divergence in many marine species. The two sequences of $S$. senegalensis clustered together with a bootstrap value of $100 \%$, suggesting small divergence between both regions in this species. However, the two sequences of $S$. lascaris did not cluster togeth$\mathrm{er}$, the sequence of $S$. lascaris from the Mediterranean area appeared more closely related to $S$. impar than to $S$. lascaris from the Atlantic. Borsa and Quignard (2001), also obtained this result, and this together with the genetic distances obtained in the present work (S. lascaris Mediterranean area- $S$. lascaris Atlantic area $=0.031 ; \quad S$. lascaris Mediterranean area-S. impar $=0.012$ ), point to the existence of an important geographic differentiation in this species, as well as that $S$. impar could be another assemblage of the same species within the Mediterranean area. The most striking result concerned the two sequences of B. luteum. The resulting phylogenetic position of the sequence provided by Tinti et al. (2000), was totally unexpected because it appeared clustered with Lepidorhombus boscii of 


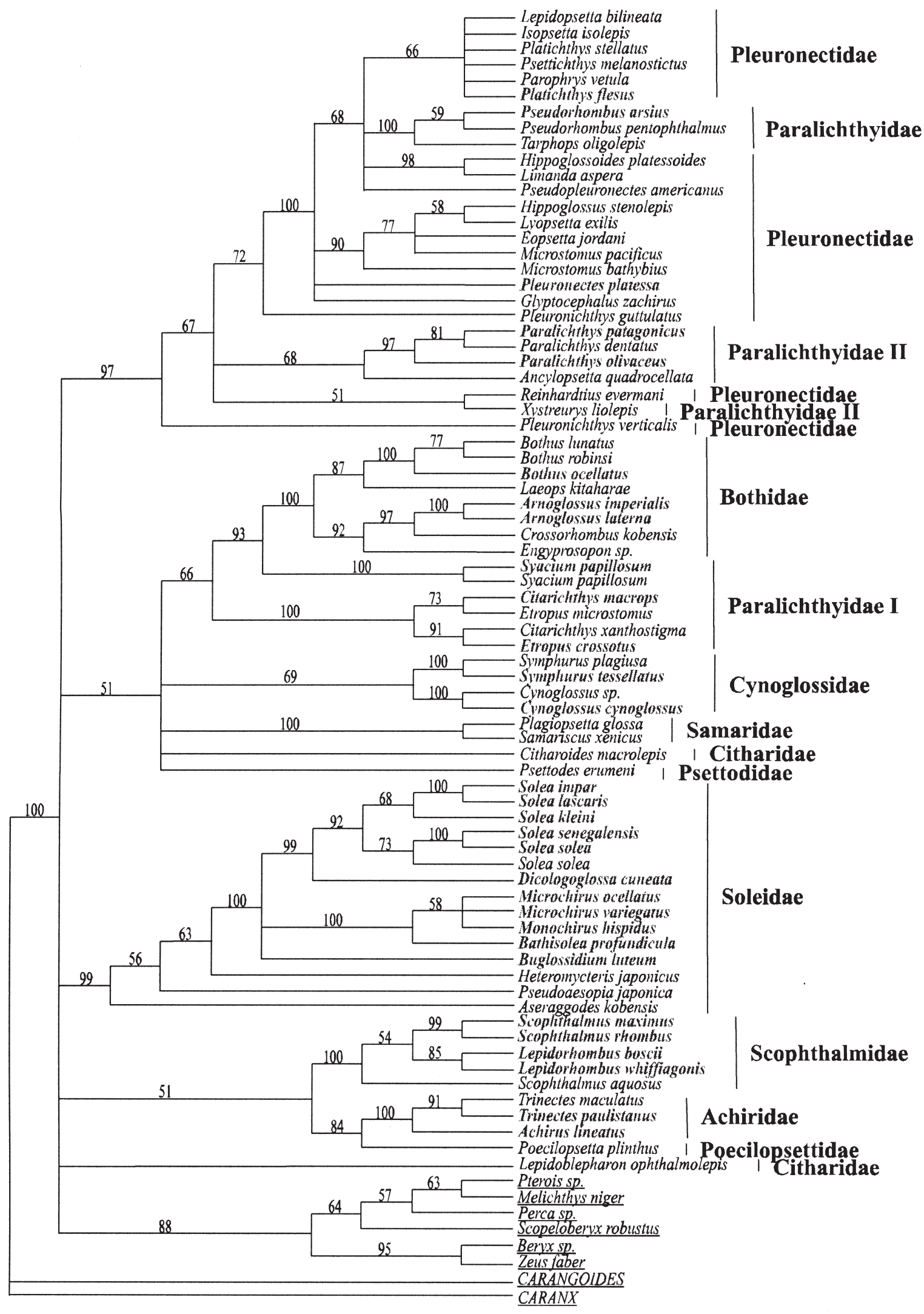

FIG. 5.- Phylogenetic relationships of the taxa studied here (bold type) and those from Berendzen and Dimmick (2002), using Bayesian inference. Two regions of doubtful alignment were eliminated from this analysis, which resulted in a $535 \mathrm{bp}$ matrix. The numbers on branches indicated the posterior probabilities according to the Bayesian method. The outgroups used appear underlined. 
the family Scophthalmidae, while our sequence from the Atlantic area was confidently placed within the soleid clade, in accordance with morphological data. This contradictory result can be explained by an incorrect classification of the specimen in the study by Tinti et al. (2000), as such a degree of divergence within a single species is not possible. This explanation could also account for the incongruent results obtained by these authors in comparison with those suggested either by morphological data (Quéro et al., 1986), or by other mtDNA data sets (Tinti et al., 2000).

In summary, we have initiated the way towards a unifying hypotheses regarding pleuronectiform phylogeny, by combining analyses of mtDNA sequences and previous chromosomic and morphologic data. However, further work remains to be done with additional information from more slowly evolving genome segments to provide new data at the most internal nodes where flatfish phylogeny remains unclear.

\section{ACKNOWLEDGEMENTS}

The authors would like to thank Zakir Hossain for the samples supplied. We are also grateful to Peter Berendzen for kindly providing us with the data matrices of his sequences to include them in our analyses. This study was supported by FEDER funds from the Spanish Government (IFD97-2404).

\section{REFERENCES}

Ahlstrom, E.H., K. Amaoka, D.A. Hensley, H.G. Moser and B.Y. Sumida. - 1984. Pleuronectiformes: development. In: Moser, H.G., Richards, W.J., Cohen, D.M., Fahay, M.P., A.W. Kendall and S.L. Richardson (eds.), Ontogeny and Systematics of Fishes, pp. 640-670. Am. Soc. Ichthyo. Herp. Special Publication 1.

Alves-Gómes, J.A., G. Ortí, M. Haygood, W. Heiligenberg and A. Meyer. - 1995. Phylogenetic analysis of the south american electric fishes (Order Gymnotiformes) and the evolution of their electrogenic system: a sinthesis based on morphology, electrophysiology, and mitochondrial sequence data. Mol. Biol. Evol., 12: 298-318.

Amaoka, K. - 1969. Studies on the sinistral flounders found in the waters around Japan. Taxonomy, anatomy and phylogeny. $J$. Shimonoseki. Univ. Fish., 18: 65-340.

Berendzen, P.B. and W.W. Dimmick. - 2002. Phylogenetic relationship of Pleuronectiformes based on molecular evidence. Copeia, 3: 642-652.

Blanquer, A. - 1990. Phylogeographie intraspecifique d'un poisson marin, le flet Platichthys flesus L. (Heterosomata). Polymorphisme des marqueurs nucleaires et mitochondriaux. $\mathrm{Ph}$. D. thesis, Univ. Montpellier.

Borsa, P. and J.P. Quignard. - 2001. Systematics of the AtlanticMediterranean soles Pegusa impar, P. lascaris, Solea aegyptiaca, S. senegalensis, and S. solea (Pleuronectiformes: Soleidae). Can. J. Zool., 79: 2297-2302.
Brown, W.M. - 1985. The mitochondrial genome of animals. In: R.J. Macintyre (ed.), Molecular Evolutionary Genetics, pp. 95130. Plenum Press, New York.

Chabanaud, P. - 1949. Le problème de la phylogénèse des Heterosomata. Bull. Inst. Oceanogr. (Monaco), 950: 1-24.

Chapleau, F. - 1993. Pleuronectiform relationships: a cladistic reassessment. Bull. Mar. Sci., 52: 516-540.

Chapleau, F. and A. Keast. - 1988. A phylogenetic reassessment of the monophyletic status of the family Soleidae, with notes on the suborder Soleoidei. Can. J. Zool., 66: 2797-2810.

Cooper, J.A. and F. Chapleau. - 1998. Phylogenetic status of Paralichthodes algoensis (Pleuronectiformes: Paralichthodidae). Copeia, 2: 477-481.

Dixon, M.T. and D.M. Hillis. - 1993. Ribosomal RNA secondary structure: compensatory mutations and implications for phylogenetic analysis. Mol. Biol. Evol., 10: 256-267.

Exadactylos, A. and J.P. Thorpe. - 2001. Allozyme variation and genetic inter-relationships between seven flatfish species (Pleuronectiformes). Zool. J. Linn. Soc., 132: 487-499.

Farias, I.P., G. Ortí, I. Sampaio, H. Schneider and A. Meyer. 1999. Mitochondrial DNA phylogeny of the family Cichlidae: monophyly and fast molecular evolution of the Neotropical assemblage. J. Mol. Evol., 48: 703-711.

Felsenstein, J. - 1985. Confidence limits on phylogenies: an approach using the bootstrap. Evolution, 39:783-791.

Hanel, R. and C. Sturmbauer. - 2000. Multiple recurrent evolution of trophic types in Northeastern Atlantic and Mediterranean seabreams (Sparidae, Percoidei). J. Mol. Evol., 50: 276-283.

Hensley, D.A. - 1997. An overview of the systematics and biogeography of the flatfishes. J. Sea Res., 37: 187-194.

Hensley, D.A. and E.H. Ahlstrom. - 1984. Pleuronectiformes: relationships. In: Moser, H.G., Richards, W.J., Cohen, D.M., Fahay, M.P., A.W. Kendall and S.L. Richardson (eds.), Ontogeny and Systematics of Fishes, pp. 670-687. Am. Soc. Ichthyo. Herp. Special Publication 1.

Hillis, D.M. - 1998. Taxonomic sampling, phylogenetic accuracy, and investigator bias. Syst. Biol., 47: 3-8.

Hubbs, C.L. - 1945. Phylogenetic position of the Citharidae, a family of flatfishes. Misc. Publ. Museum. Zool. Univ. Mich., 63: 1-38.

Huelsenbeck, J.P. and F.R. Ronquist. - 2001. MRBAYES: Bayesian inference of phylogeny. Bioinformatics, 17: 754-755.

Johnson, G.D. and C. Patterson. - 1993. Percomorph phylogeny: a survey of acanthomorphs and a new proposal. Bull. Mar. Sci., 52: 554-626.

Kikuno, T., Y. Ojima and N. Yamashita. - 1986. Chromosomes of flounder, Paralichthys olivaceus. Proc. Jap. Acad., 62B: 194196.

Kyle, H.M. - 1921. The asymmetry, metamorphosis and origin of flat-fishes. Phil. Trans. Roy. Soc. London (B), 211: 75-128.

Lauder, G.V. and K.F. Liem. - 1983. The evolution and interrelationships of the actinopterygian fishes. Bull. Mus. Comp. Zool., 150: 95-197.

Lavane, C., G. Preparata, C. Saccone and G. Serio. - 1984. A new method for calculating evolutionary substitution rates. J. Mol. Evol., 20: 86-93.

Le, H.L., G. Lecointre and R. Perasso. - 1993. A 28S rRNA-based phylogeny of the gnathostomes: first steps in the analysis of conflict and congruence with morphologically based cladograms. Mol. Phylogenet. Evol., 2: 31-51.

Le Grande, W.H. - 1975. Karyology of six species of Lousiana flatfishes (Pleuronectiformes: Osteichthyes). Copeia, 3: 516-522.

Mindell, D.P. and R.L. Honeycutt. - 1990. Ribosomal RNA in vertebrates: evolution and phylogenetic applications. Annu. Rev. Ecol. Syst. 21: 541-566.

Nelson, J.S. - 1994. Fishes of the world, 3rd ed. John Wiley \& Sons, New York.

Norman, J.R. - 1934. A systematic monograph of the flat-fishes (Heterosomata), vol. 1. British Museum (Natural History), London.

Orti, G. - 1997. Radiation of characiform fishes: evidence from mitochondrial and nuclear DNA sequences. In: T.D. Kocher and C.A. Stepien (eds.), Molecular Systematics of Fishes, pp. 219-243. Academic Press, San Diego, California.

Palumbi, S., A. Martin, S. Romano, W.O. McMillan, L. Stice and G. Grabowski. - 1991. The Simple Fool's Guide to PCR. University of Hawaii, Honolulu, HI.

Pardo, B.G., C. Bouza, J. Castro, P. Martínez and L. Sánchez. 2001. Localization of ribosomal genes in Pleuronectiformes 
using Ag-, CMA3-banding and in situ hybridization. Heredity, 86: $1-6$.

Patro, R. and R. Prasad - 1981. Chromosomal studies in five indian flatfishes. Copeia, 2: 498-503.

Posada, D. and K.A. Crandall. - 1998. MODELTEST: testing the model of DNA substitution. Bioinformatics, 14: 817-818.

Quéro, J.C., M. Desoutter and F. Lagardere. - 1986. Soleidae. In: P.J. Whitehead, M.L. Bauchot, J.C. Hureau, J. Nielsen and E. Tortonese (eds.), Fishes of the North-eastern Atlantic and the Mediterranean, vol. 3, pp. 1308-1328. Unesco, Paris, France.

Regan, C.T. -1910 . The origin and evolution of the teleostean fishes of the order Heterosomata. Ann. Mag. Nat. Hist., 6: 484-496.

Rodríguez, F., J.L. Oliver, A. Marín and J.R. Medina. - 1990. The general stochastic model of nucleotide substitution. J. Theor. Biol., 142: 485-501.

Saitoh, K., M. Tanaka, R. Ueshima, T. Kamaishi, T. Kobayashi and K. Numachi. - 1995. Preliminary data on restriction mapping and detection of lengh variation in Japanese flounder mitochondrial-DNA. Aquaculture, 136: 109-116.

Sambrook, J., E.F. Fritsch and T. Maniatis. - 1989. Molecular Cloning: A Laboratory Manual. Cold Spring Harbor Laboratory Press, Cold Spring Harbor, New York.

Smith, A.B. - 1994. Rooting molecular trees: problems and strategies. Biol. J. Linn. Soc., 51: 279-292.

Sola, L., S. Cataudella and E. Capanna. - 1981. New developments in vertebrate cytotaxonomy. III. Karyology of bony fishes: a review. Genetica, 54: 285-328.

Stepien, C.A., A.K. Dillon, M.J. Brooks, K.L. Chase and A.N Hubers. - 1997. The evolution of Blennioid fishes based on an analysis of mitochondrial 12S rDNA. In: T.D Kocher and C.A. Stepien (eds.), Molecular Systematics of Fishes, pp. 245-270. Academic Press, San Diego, California.

Swofford, D.L. - 2000. PAUP*: Phylogeny Analysis Using
Parsimony (*and other methods), version 4.0b3. Sinauer, Suderland, MA.

Thompson, J.D., T.J. Gibson, F. Plewniak, F. Jeanmougin and D.G. Higgins. - 1994. The CLUSTAL_X windows interface: flexible strategies for multiple sequence alignment aided by quality analysis tools. Nucleic. Acids. Res., 25: 4876-4882.

Tinti, F. and C. Piccinetti. - 2000. Molecular systematics of the Atlanto-Mediterranean Solea species. J. Fish. Biol., 56: 604614.

Tinti, F., A. Colombari, M. Vallisneri, C. Piccinetti and A.M. Stagni. - 1999. Comparative analysis of a mitochondrial DNA control region fragment amplified from three Adriatic flatfish species and molecular phylogenesis of Pleuronectiformes. Mar. Biotechnol., 1: 20-24.

Tinti, F., C. Piccinetti, S. Tommasini and M. Vallisneri. - 2000 Mitochondrial DNA variation, phylogenetic relationships, and evolution of four Mediterranean genera of soles (Soleidae, Pleuronectiformes). Mar. Biotechnol., 2: 274-284.

Tringali, M.D., T.M. Bert, S. Seyoum, E. Bermingham and D. Bartolacci. - 1999. Molecular phylogenetics and ecological diversification of the transisthmian fish genus Centropomus (Perciformes: Centropomidae). Mol. Phylogenet. Evol., 13: 193-207.

Vernau, O., C. Moreau, F.M. Catzeflis and F. Renaud. - 1994. Phylogeny of flatfishes (Pleuronectiformes): comparisons and contradictions of molecular and morpho-anatomical data. $J$. Fish. Biol., 45: 685-696.

Vitturi, R., R. Catalano and D. Colombera. - 1993. Chromosome analysis of Bothus podas (Pisces, Pleuronectiformes) from the Mediterranean Sea. J. Fish. Biol., 43: 221-227.

Scient. ed.: F. Piferrer 
